\title{
Poly(vinylpyridine oxides) in pneumoconiosis research
}

\author{
P. F. HOLT \\ Department of Chemistry, University of Reading
}

\begin{abstract}
Holt, P. F. (1971). Brit. J. industr. Med., 28, 72-77. Poly(vinylpyridine oxides) in pneumoconiosis research. Schlipköter and Brockhaus of the Institut für Lufthygiene Düsseldorf found that poly(2-vinylpyridine 1-oxide) can inhibit the fibrosis normally produced by quartz dust in the lungs or other tissues of animals. Later research in Germany and elsewhere has confirmed the earlier observations. The polymer is active when the quartz is administered by intratracheal, intraperitoneal or intravenous injection or by inhalation. It is effective if given in aqueous solution by intraperitoneal or subcutaneous injection or if it is inhaled as an aerosol.

The polymer also counteracts the cytotoxic effects of finely divided quartz in cultures of alveolar or peritoneal macrophages and a rapid method for comparing the activity is based on this observation. Although some solutions of this and other polymers which show activity against quartz in cultures are less active against quartz in the whole animal, a polymer which proves inactive against quartz in cultures is invariably inactive in the whole animal.

The degree of activity of this polymer depends on the molecular weight, low molecular weight being associated with low activity. Methyl groups substituted in the pyridine ring may reduce the activity or may have no effect, depending on the position of the group in the ring. The isotactic and syndiotactic forms of the polymer do not have identical effects. Poly(2vinylpyridine 1-oxide) is not unique; poly(dimethylaminostyrene $\mathrm{N}$-oxide) is almost equally effective.

Several theories seek to explain the activity of this polymer against quartz but there is uncertainty, particularly because the mechanism by which silica damages cells and produces fibrosis is still in doubt. Damage to the membrane of the cell or its ultrastructures by silica has been suggested as a possible cause of cytotoxicity; it has been suggested that the polymer may shield these structures. Other suggestions are that the polymer coats the surface of the quartz or combines with silicic acid by forming hydrogen bonds.
\end{abstract}

When finely divided quartz is introduced into the lung of an animal by inhalation or injection, fibrosis of the lung results. Similarly, if the quartz is injected into the peritoneal cavity, fibrous nodules are produced. Schlipköter and Brockhaus (1960) demonstrated that if the quartz (50 mg) was injected as a suspension in a $1 \%$ solution of poly(2-vinylpyridine) (I) or poly(4-vinylpyridine) (II) in dilute acid, minimal fibrosis followed. The reduction of fibrosis was demonstrated histologically and by chemical estimation of the collagen in the tissue. It seemed probable that the polymers coated the silica particles and rendered them inocuous.

These polymers are insoluble in water at $p \mathrm{H} 7$. They are soluble in dilute hydrochloric acid but if an acid solution of either is injected into an animal, the free base is precipitated. Schlipköter and Brockhaus found that there was no significant effect on the fibrogenic response to quartz if the quartz and solution of polymer in acid were injected separately.

Schlipköter and Brockhaus (1961) oxidized the polymers with hydrogen peroxide in acetic acid, 
producing the very soluble poly(vinylpyridine 1-oxides) which had not previously been described. Quartz that was administered to rats by intraperitoneal injection was found to produce little fibrosis if poly(2-vinylpyridine 1-oxide) PVNO (III) in aqueous solution was also administered by subcutaneous injection. A reduction in the rate of fibrogenesis followed even when the PVNO was not administered until 30 days after the quartz.

Dolgner, Brockhaus, and Schlipköter (1965) found that PVNO almost completely inhibited quartz fibrosis in animals when given subcutaneously, but they found it much less effective if given by inhalation and ineffective if given by mouth. Later experiments have shown that PVNO can be very active if inhaled as an aerosol. It was found to inhibit fibrosis in rats when quartz was administered by intratracheal or intraperitoneal injection, in guinea-pigs when given by intraperitoneal injection, and in mice when given by intratracheal or intravenous injection. It was almost ineffective when mice were given quartz by intraperitoneal injection. Little fibrosis developed in the lungs and lymph glands of rats that had inhaled quartz dust if PVNO was given by subcutaneous injection. The polymer increased the elimination of dust when rats had severe established fibrosis in the lungs, and it inhibited the development of the lesions and even produced a decrease in the collagen content of the lungs.
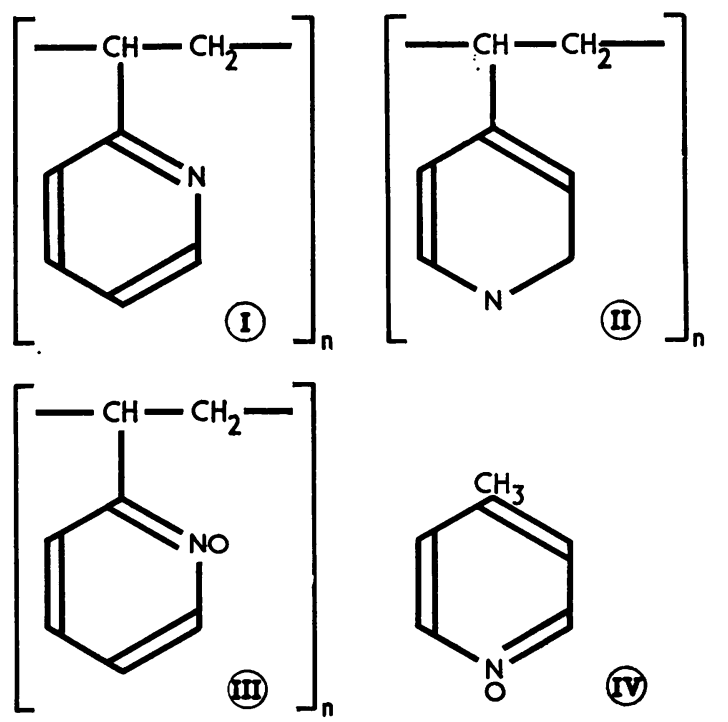

Schlipköter (1966) summarized the results of investigations on the use of PVNO to counteract silica. The protective action of PVNO in whole animals was confirmed by Barhad, Rotaru, Petrescu, and Lazărescu (1967) using rats that were given silica by intratracheal injection and the polymer immediately afterwards by the same route. Recently, Klosterkötter and Gono (1969) have shown that inhaled quartz (240 hours during 3 months, concentration $10 \mathrm{mg} / \mathrm{m}^{3}$ ) behaved like an inert dust in the lungs of rats when an aerosol of PVNO solution was inhaled once weekly for 1 hour.

Dolgner et al. (1965) found that a monomeric analogue of polymer (II), 4-methylpyridine 1-oxide (IV), was completely inactive when given subcutaneously to animals that had received quartz by intratracheal injection and the activity of the polymer was shown (Schlipköter and Brockhaus, 1961) to be related to its molecular weight. The molecular weights were assessed by measuring the viscosity of the polymer solutions, the intrinsic viscosity $[\eta]$ is proportional to the average molecular weight. Solutions of PVNO having intrinsic viscosities of $[\eta]=121 \times 10^{3}, 83 \times 10^{3}$, and $69 \times 10^{3}$ almost completely inhibited quartz fibrogenesis in rats if injected subcutaneously: a solution of lower viscosity, $[\eta]=14 \times 10^{3}$, was much less active, the inhibition being marked only after 60 days.

\section{Fibrosis in other organs}

PVNO is active against silica-induced fibrogenesis in organs other than the lung. Mohn (1965) produced granulomas in the livers of rats by injecting colloidal silicic acid into the tail vein. The liver collagen was increased but the change was counteracted when PVNO was also injected. Hennies, Eger, and Eger (1967) produced changes in the liver and spleen of rats by injecting alkali-treated quartz dusts but fibrosis was inhibited - never completely but up to an estimated $90 \%$ - by subcutaneous injections of PVNO. A 30 to $50 \%$ regression of the silica granulomas was found when PVNO was administered to animals with established fibrosis in the liver and spleen.

\section{Cell cultures}

Marks and Mason (1956) demonstrated that cells which phagocytosed finely divided quartz in cultures of macrophages were killed and the death of macrophages is regarded as the stage preceding the fibrotic response to silica. Most other dusts, such as corundum, are actively phagocytosed but do not appear to damage the cells. The cell culture technique has proved invaluable in assessing the efficiency of various substances in counteracting the pathogenic effects of silica. Cultures of several types have been used, including mouse fibroblasts and alveolar and peritoneal macrophages of guinea-pigs.

Beck, Bruch, and Brockhaus (1963) described experiments in which quartz was added to a culture of mouse fibroblasts (strain L). Some cultures were 
first treated with PVNO and then washed before quartz was added; other cultures received quartz that had been pretreated with the polymer. The effect of the dust was estimated by counting the number of living cells remaining after specified intervals of time (the dying cell becomes rounded and no longer produces processes). When protected by PVNO, many cells in these cultures survived in the presence of quartz and the curves showing cell count against time resembled the control curves relevant to cultures that contained no quartz.

Subsequent investigations have confirmed and extended these results. By measuring the oxygen consumption of the cultures, Beck, Santer, Bruch, and Brockhaus (1964) demonstrated an arrest of metabolism when quartz was added to mouse fibroblasts, which was partially counteracted if the cells were first treated with PVNO and then washed before the quartz was added. The polymer alone had no effect on the metabolism of the cells. A similar result was reported by Marchisio and Comolli (1964). Rasche and Ulmer (1964) showed the protective action of PVNO on cultures by measuring the rate of lactic acid synthesis by the cells. When quartz was added to the culture, synthesis was inhibited, but if PVNO was added to the nutrient fluid or the dust, the rate of lactic acid synthesis was similar to that of control cultures containing no quartz. Koshi and Sakabe (1966) demonstrated an increase in acid phosphatase in the supernatant fluid in which macrophages were cultured when some varieties of silica were added; the increase was prevented by PVNO. Plainly, the culture method provided a rapid and sensitive method for assessing the activity of polymers against pathogenic effects of quartz.

Schlipköter and Beck (1965) came to the conclusion that tests with cell cultures could not entirely replace tests on animals. They tested the effects of a number of polymers of various activities, measuring the rate of lactic acid synthesis in cell cultures containing quartz with and without polymers and the collagen produced in the lung or peritoneum of animals to which quartz had been administered by intratracheal or intraperitoneal injection. Generally, the results agreed very well but there were anomalies and the authors concluded that (1) a compound that is ineffective in tests with cultures will be ineffective in experimental animals, and (2) some polymers which protect macrophages against quartz in cultures are ineffective in animals. They concluded that cultures were useful as a preliminary screen but that subsequent tests with animals on apparently active compounds were essential. A review has been published by Beck (1970).

\section{Mechanism}

Schlipköter and Brockhaus (1961) discussed mechan- isms by which the polymer might inhibit fibrosis. One possibility was that the quartz was coated by the organic material and they demonstrated that PVNO was, in fact, adsorbed from an aqueous solution on to a quartz surface to produce a layer. Other polymers were similarly adsorbed, however, and there seemed to be no relation between the ability of the polymer to counteract the pathogenic effects of quartz and the degree of adsorption. Polyvinylimidazol, for example, is ineffective against quartz but shows an adsorption isotherm closely resembling that of PVNO (Schlipköter and Brockhaus, 1963).

Beck and Boje (1967) used a radioactive $\left({ }^{14} \mathrm{C}\right.$ labelled) PVNO and microcinematography to show that the polymer is pinocytosed by phagocytic primary and established cells in cultures and that it is concentrated in vacuoles and lysosomes. Bruch (1967) used electron microscopy to examine cells which had pinocytosed PVNO and he described sub-microscopic changes.

Bairati and Castano (1968) examined sections of the livers of mice that had received PVNO. By electron microscopy they found vacuoles in the Kupffer cells which they assumed to be accumulations of the polymer in phagosomes but there were no morphological changes. As these cells also take up silica, it is apparent that the protective polymer and the silica are brought into contact by this mechanism.

Marchisio and Comolli (1964), from studies on the protection of peritoneal macrophages against quartz by PVNO, which included observations on the rate of incorporation of isotopically labelled leucine into protein by the cells, suggested that the polymer either shielded ultrastructures of the cells or inactivated the silica but they favoured the latter hypothesis.

Antweiler (1963) concluded that PVNO caused a change in the behaviour of the macrophage towards the phagocytosed quartz particles and the silicic acid resulting from its dissolution but he found that PVNO had no effect on the phagocytosis of quartz particles by rat or guinea-pig macrophages either in vivo or in vitro.

Allison, Harington, and Birbeck (1966) suggested that the toxic action of quartz may be due to its effect on the lysosomal membranes causing enzymes of the lysosomes to leak into the cytoplasm of the cell. Quartz certainly increases the amount of acid phosphatase leaking from isolated lysosomes in vitro. These authors demonstrated by a histological technique developed by Jancsó (described by Pearse, 1968) for demonstrating polyvinylpyrrolidone that pinocytosed PVNO is stored in lysosomes.

Nash, Allison, and Harington (1966), concluding that the toxic effects of silica are due to polymeric silicic acid acting as a hydrogen donor in the 
formation of hydrogen-bonded complexes, believed that PVNO preferentially forms hydrogen bonds with silicic acid and prevents the permeability changes induced by the silicic acid in biological membrane systems.

Poly(4-vinylpyridine 1-oxide), which forms similar hydrogen bonds but has a low activity, and the quaternary poly(2-vinylpyridine 1-methoxy iodide), which would not form such bonds but is as active as PVNO, are anomalous. Hydrogen bonding of polyvinylpyridines with silicic acid has been studied using 2-alkylpyridine oxide and 4-alkylpyridine oxide monolayers as model systems (Holt and Nasrallah, 1969). Intramolecular bonding in polymers (I) and (II) and their reaction with silicic acids have been studied by ultraviolet spectroscopy, proton magnetic resonance, viscosity and $p \mathrm{H}$ titration curves (Holt and Nasrallah, 1968; Holt and Lindsay, 1969; Holt and Tamami, 1970).

Dehnen and Fetzer (1967) demonstrated that PVNO would stabilize isolated rat liver lysosomes in the presence of quartz. The polymer was effective both when the quartz was pretreated and when the lysosomes were pretreated.

Cavagna and Nichelatti (1963) suggested that the polymer prevented the toxic action of quartz by interfering with the enzymic processes which damaged the cell. Beck and Antweiler (1963) and Schlipköter (1964) suggested that PVNO may influence enzyme reactions in the macrophages or produce a non-specific increased resistance which stabilizes cell membranes.

\section{Erythrocytes}

Antweiler (1963) found that the sedimentation rate of human, rat, guinea-pig and rabbit erythrocytes was considerably increased if PVNO was added to the citrated plasma but there was no change in the rate if cells were treated with PVNO and then washed. If PVNO was present in the solution, erythrocytes were less liable to be haemolysed but pre-treatment of the cells was ineffective.

Czentei (1967) showed that quartz would haemolyse a suspension of erythrocytes but that PVNO in the fluid retarded the haemolysis and she suggested that this system might act as a model in testing the protective action of polymers against quartz. She found that high molecular weight polyvinylpyrrolidone $(\mathrm{MW}=350,000)$ had the same effect but that dextrans were ineffective.

\section{Other polymers}

The demonstration of the remarkable activity of PVNO encouraged the examination of other polymers. Polyvinylpyrrolidone was shown by Mohn (1963) to be slightly active against the fibrogenic effects of colloidal silicic acid injected intravenously into rats.

Marchisio, Pernis, Vigliani, and Ferruti (1965) and Ferruti and Marchisio (1966) found that some other polymer $\mathrm{N}$-oxides protected guinea-pig macrophages in cultures against the cytotoxic effects of silica including poly(3-vinylpyridine 1-oxide), poly(4vinylpyridine 1-oxide) and poly $(\mathrm{N}$-allylpiperidine 1-oxide). Other active polymers contained no pyridine ring but all contained the $\mathrm{N}$-oxide group, namely, poly(p-dimethylaminostyrene $\mathrm{N}$-oxide), poly(N-allyl-N,N-dimethylamino-N-oxide), poly(Nallyl-N,N-diethylamino- $\mathrm{N}$-oxide) and poly[ $\mathrm{N}$-allyl$\mathrm{N}$-isopropyl- $\mathrm{N}-\beta$ (4 morpholin) ethylamine di-N,Noxide]. They concluded that $\mathrm{N}$-oxide was the active group in the polymers.

Holt, Lindsay, and Beck (1970) prepared a number of polymers that were closely related to PVNO and tested them on macrophage cultures. Each polymer was tested by pre-treating the macrophages, washing them, and then adding quartz dust, and also by pre-treating the quartz, washing it, and then adding it to the culture. Every polymer was active in one or other of the tests but some were inactive by one test. Some poly(2-vinylpyridinium) salts, polymers which did not contain the $\mathrm{N}$-oxide group, were found to be active against quartz in cultures. Most, but not all, of the results could be explained by assuming that the polymers formed an adsorbed layer on the quartz. An interesting difference was found between the effects of syndiotactic and isotactic PVNO, polymers that differ only in the spatial arrangement of the structural units.

\section{Toxicity tests}

Grundmann $(1967,1968)$ reported that he found no acute toxic symptoms in Wistar rats that had been given PVNO. He gave one group repeated weekly subcutaneous injections ( $1 \mathrm{ml}$ of a $2 \%$ solution), killing them after 23 days, and another group a single intravenous injection of $5 \mathrm{ml}$ of a $2 \%$ solution, killing animals after periods varying from 24 to 240 hours. Cryostat sections of the kidney were examined for eight enzymes but no reduction in activity was observed. He concluded that 'The organ that preferentially eliminates PVNO does not show any histologically or histochemically demonstrable reduction in activity associated with excretion and reabsorption'.

Schmähl (1969), working at the German Cancer Research Centre at Heidelberg, injected up to 3.75 $\mathrm{g} / \mathrm{kg}$ body weight of PVNO into Wistar rats and ICI strain mice but could find no carcinogenic effects attributable to the polymer. The animals were kept up to 800 days. No toxic symptoms were observed and the increase in weight of the injected animals corresponded to that of the controls. 
There is a wide interest in PVNO and related polymers both with respect to their ability to prevent the fibrogenic effects of silica in animals and to inhibit its cytotoxic effects in cultures. The discovery of the activity of this group of polymers represents one of the most promising advances in the field of pneumoconiosis. They have proved to be a valuable tool in silicosis research and the hope has been expressed (Schlipköter, 1964) that it may be found possible to apply them in the field of chemoprophylaxis or even chemotherapy. Clinical tests have begun (Schlipköter, 1970).

\section{References}

Allison, A. C., Harington, J. S., and Birbeck, M. (1966). An examination of the cytotoxic effects of silica on macrophages.J. exp. Med. 124, 141-153.

Antweiler, H. (1963). Tierexperimentelle Untersuchungen zur Wirkungsweise des Polyvinylpyridin-N-oxyds (P 204). Beitr. Silikose-Forsch. Sonderband Grundfragen Silikoseforschung, 5, 153-169.

Bairati, A., and Castano. P. (1968). Studio al microscopio elettronico della localizzazione, nel fegato dei topi, di polimeri sintetic citoprotettiri nei confronti della silice. Med. $d$. Lavoro, 59, 81-104.

Barhad, B., Rotaru, G., Petrescu, L., and Lazărescu, I. (1967) Veränderungen in vivo der alveolären Koniophagen unter dem Einfluss des Siliciumdioxyds und des Polyvinylpyridine-N-oxids. Int. Arch. Gewerbepath. Gewerbehyg., 24, 148-153.

Beck, E. G. (1970). Die Reaktion in vitro gəzüchteter Zellen auf partikelförmige Luftyerunreinigungen und hochpolymere Stoffe. Forschungsberichte des Landes Nordrhein-Westfalen No. 2083. Westdeutscher Verlag, Köln and Opladen.

, and Antweiler, H. (1963), Experimentelle Untersuchungen zum Wirkungsmechanismus des Fibrosehemmers Polyvinyl-pyridinN-oxid. XIV Int. Congr. occup. Hlth Madrid, 1963, Vol. 3, pp. 1160-1164. Excerpta Medica Int. Congr. Ser. No. 62. , and Boje, H. (1967). Zytologische Untersuchungen über die Wirkung von Poly-2-vinylpyridin-N-oxid in der Zellkultur. Edited by Reploh, H., and Einbrodt, H. J. Fortschritte der Staublungenforschung, vol. 2, pp. 231-236. Niederrheinische Drückerei, Dinslaken.

—, Bruch, J., and Brockhaus, A. (1963). Die Beeinflussung der cytotoxischen Quarzwirkung an Mäusefibroblasten (Strain L) durch Polyvinylpyridin-N-oxyd (P 204). Z. Zellforsch., 59, 568-576.

- Santer, A., Bruch, J., and Brockhaus, A. (1964). Biochemische Untersuchungen über die Staubphagocytose an einem etablierten Zellstamm (strain L 929) und über die Beeinflussung der cytotoxischen Quarzwirkung durch Polyvinylpyridin-N-oxyd (P 204). Z. Naturforsch., 19b, 606-612.

Bruch, J.(1967). Submikroskopische Beobachtungen nach kurzzeitige Applikation von Poly-2-vinylpyridin-N-oxid. In Fortschritte der Staublungenforschung, vol. 2, pp. 273-276. Edited by Reploh, H., and Einbrodt, H. J. Niederrheinische Drückerei, Dinslaken.

Cavagna, G., and Nichelatti, T. (1963). The protective influence of polyvinylpyridine-N-oxide in experimental silicosis. Med. $d$. Lavoro, 54, 621-627.

Czentei, E. (1967). Die Hämolyse durch Quarzstaub und ihre Hemmung. Ergebnisse von Untersuchungen auf dem Gebiet der Staub- und Silikosebekämpfung im Steinkohlenbergbau. Vol. 6, pp. 149-156. Bösmann, Detmold.

Dehnen, W., and Fetzer, J. (1967). Uber die Wirkung von Polyvinylpyridin-N-oxid (P 204) auf die Stabilität isolierter Rattenleberlysosomen. Ergebnisse von Untersuchungen auf dem Gebiet der Staub- und Silikosebekämpfung im Steinkohlenbergbau. Vol. 6, p. 161-162. Bösmann, Detmold.

Dolgner, R., Brockhaus, A., and Schlipköter, H. W. (1965). Neuere Untersuchungen zum Einfluss von Polyvinylpyridin-N-oxid auf die experimentelle Silikose. Beitr. Silikose-Forsch. Sonderband. Grundfragen Silikoseforschung, 6, 213-231.
Ferruti, P., and Marchisio, M. A. (1966). Blocco dell'azione citolesiva della silice 'in vitro' mediante polimeri sintetici contenenti il gruppo $\mathrm{N} \rightarrow \mathrm{O}$. Med. d. Lavoro, 57, 481-491.

Grundmann, E. (1967). Experimentelle Untersuchungen über die zelluläre Speicherung des Polyvinylpyridin-N-oxids. In Fortschritte der Staublungenforschung, vol. 2, pp. 223-229. Edited by Reploh, H. and Einbrodt, H. J. Niederrheinische Drückerei, Dinslaken.

- Goslar, H. G., Bartels, C. and Jungck, E. (1968). Histologische und enzymhistologische Unterssuchungen an Rattennieren nach Polyvinylpyridin-N-oxid. Beitr. path. Anat., 138-147.

Hennies, H., Eger, K., and Eger, W. (1967). Präventive und kurative silikotrope Wirkung des Polyvinylpyridin-N-Oxid im Leber- und Milz-Test. Beitr. Silikose-Forsch., Heft 93, 15-31.

Holt, P. F., and Lindsay, H. (1969). Poly(alkylpyridine 1-oxides) and corresponding alkylpyridine oxides: electronic spectra and interaction with silicic acid. J. chem. Soc. (B), 54-61. Isotactic and syndiotactic poly(2-vinylpyridine 1-oxide) and 2-vinylpyridine oxide-2-n-propenylpyridine oxide copolymer: nuclear magnetic resonance and ultraviolet spectra, viscosities and reaction with silicic acids. J. chem. Soc. (C). 1012-1015.

- and Beck, E. G. (1970). Some derivatives of polyvinylpyridine l-oxides and their effect on the cytotoxicity of quartz in macrophage cultures. Brit. J. Pharmacol., 38, 192-201.

- and Nasrallah, E. T. (1968). The interaction of poly(2-vinylpyridine 1-oxide) and poly(4-vinylpyridine 1-oxide) with monosilicic acid. J. chem. Soc. (B), 233-237.

- - (1969). Alkylpyridine oxide monolayers as analogues of poly(vinylpyridine oxides): a study of the interaction of heptadecylpyridine oxides with monosilicic acid. J. chem. Soc. (C), 823-826.

, and Tamami, B. (1970). Isotactic, syndiotactic and atactic poly(vinylpyridine 1-oxide): relation between viscosity in aqueous solution and $\mathrm{pH}$. Polymer. In the press.

Klosterkötter, W., and Gono, F. (1969). Uber den Einfluss von Polyvinylpyridin N-oxid -Aerosol auf die Retention, Penetration und Elimination von Quarz. Ergebnisse von Untersuchungen auf dem Gebiet der Staub- und Silikosebekämpfung im Steinkohlenbergbau, 7, 159-164. Bösmann, Detmold.

Koshi, K., and Sakabe, H. (1966). Increase of acid phosphatase activity in the macrophages by quartz particles. Industr. Hlth (Kawasaki), 4, 16-29.

Marchisio, M. A., and Comolli, R. (1964). Studio metabolico e morfologico dell' attività liticoprotettiva della poli-2-vinilpiridina-N-ossido su macrofagi peritoneali trattati con silice. Med. d. Lavoro, 55, 401-410.

_- Pernis, B., Vigliani, E. C., and Ferruti, P. (1965). Prevenzione della silicosi sperimentale con polimeri sintetici. Med. d. Lavoro, 56, 531-534.

Marks, J., and Mason, M. A. (1956). A quantitative technique for studying the effect of dust on phagocytic cells in vitro. Brit. J. industr. Med., 13, 192-195.

Mohn, G.(1963). Histopathologische Veränderung von Rattenorganen bei protrahierter intravenöser Verabreichung von kolloidaler Kieselsäure und ihre Beeinflussung durch Polyvinylpyrrolidon. Beitr. Silikose-Forsch., Sonderband. Grundfragen Silikoseforsch., 5, 133-151.

(1965). Die Reaktion von Organen der Ratte auf kolloidale Kieselsäure in Gegenwart von Polyvinylpyridin-N-oxyd und Polyvinylpyrrolidon. Beitr. Silikose-Forsch., Sonderband. Grundfragen Silikoseforschung., 7, 1.

Nash, T., Allison, A. C., and Harington, J. S. (1966). Physicochemical properties of silica in relation to its toxicity. Nature (Lond.), 210, 259-261.

Pearse, A. G. E. (1960). Histochemistry, 2nd ed., p. 948. Churchill, London.

Rasche, B., and Ulmer, W. T. (1964). Über die zytotoxische Wirkung von fibrinogenem Staub auf Alveolar- und Peritonealphagozyten in vitro. Morphologie, Milchsäurebildung, Sauerstoffverbrauch. Int. Arch. Gewerbepath, Gewerbehyg., 21, 39-49.

Schlipköter, H. W. (1964). Neue Wege zur Behandlung der Silikose. In Ministerpräsident des Landes Nordrhein-Westfalen-Landesamt für Forschung Jahrbuch, 451-473.

- (1966). Neue therapeutische Möglichkeiten bei Staublungenerkrankungen. $\mathrm{Zbl}$. Arbeitsmed., 16, 221-226.

(1970). Ätiologie und Pathogenese der Silikose sowie ihre kausale Beeinflussung, Arbeitsgemeinschafi für Forschung des Landes Nordrhein-Westfalen, Heft 197, pp. 39-105. Westdeutscher Verlag, Cologne.

and Beck, E. G. (1965). Observations on the relationship between quartz cytotoxicity and fibrogenicity while testing the biological activity of synthetic polymers. Med. $d$. Lavoro, 56, 485-493. , and Brockhaus, A. (1960). The action of polyvinylpyridine on experimental silicosis. Dtsch, med. Wschr., 85, 920-923. 
- (1961). Die Hemmung der experimentellen Silikose durch subcutane Verabreichung von Polyvinylpyridin-N-Oxyd. Klin. Wschr., 39, 1182-1189.

(1963). Untersuchung zur Beeinflussung der Silikose.

Edited by Reploh, H., and Klosterkötter, W. In Fortschritte der

Staublungenforschung: Ber. IV. int. Staublungentagung, 1962,
Münster (Westfalen), pp. 397-413. Niederrheinische Drückerei, Dinslaken.

Schmähl, D. (1969) Prüfung von Polyvinylpyridin-N-oxid auf die carcinogene Wirkung bei Ratten und Mäusen. Arzneimittel-Forsch. 19, 1313-1314.

Received for publication March 31, 1970 